Reprinted from the "Proceedings of the Indian Academy of Sciences," Vol. LXXI, 1970

\title{
CHAETOGNATHS OF THE INDIAN OCEAN, WITH A KEY FOR THEIR IDENTIFICATION
}

BY

E. G. Silas and M. SRinivasan 


\title{
Teprinted from "The Proceedings of the Indian Academy of Sciencos". Vol. LXXI, No. S, Sec. B, 1970 \\ GAAETOGNATHS OF THE INDIAN OCEAN, WITH A A TEY FOR THEIR IDENTIFICATION*
}

\author{
By E. G. SIlas:* and M. SRINIVASAN** \\ Central Marine Fisheries Research Institute, Mandapam Camp) \\ Received August 21, 1969 \\ (Communicated by Dr. R. Subrahmanyan, F.A.sc.)
}

\section{Abstract}

The authors have recorded 33 species of Chatognaths belonging to four pelagic genera (Sagitta Quoy and Gaimard; Pterosagitta Costa; Krohnitta Ritter-Zahony; and Eukrohnia Ritter-Zahony) and one benthic genus (Spadella Langerhans), frcm the Indian Ocean and contiguous Seas. The dependable specific characters useful in identification are discussed and an illustrated key to the identifieation of the genera and the species is provided.

\section{INTRODUCTION}

THE fairly intensive exploration of the Indian Ocean by several countries participating in the International Indian Ocean Expedition has given adđed frupdrtance to the study of marine plankton of this region. The chaetoguaths form an important constituent of the marine zooplankton and some of the species are known to be good indicators of water masses, ocean cur rents and local hydrological changes (Bigelow, 1926; Russell, 1935 $a, 1935 b$; 1937, 1939; Fraser, 1952, and others), and of plankton communities (Russell, 1935 a, 1939; Fraser, 1949; Ponomareva, 1957, and others). Some recent works on Chaetognatha which need special mention are the diseussions on same aspects of speciation in this group of animals by David (1963); a combletely new classification of Chaetognatha proposed by Tokioka (1965 a); The zexiew of 'Chaetognaths' by Alvarino (1965); and a comprehensive review on biological studies of the chaetognaths by Ghirardelli (1968). We howe elsewhere given a resume of the earlier works on Chaetognatha from the Indian Seas (Silas and Srinivasan, 1969). To this may also be added the following recent works which have to be consulted for studies on chaeto-

\footnotetext{
- Publiphed with the permission of the Director, Central Marine Fisheries Research Institute,
} Mandapam Camp. Ketald.

- Present address: C.M.F.R.I. Sub-station, Gopala Prabhu Cross Road, Ernakulam, Cochin-11, 
gnaths of the Indian Ocean: Alvarino (1964 a, $1964 b, 1965,1967)$; David (1955, $1958 a, 1958 b, 1959,1963,1965)$; Furnestin (1958); Ghirardelli (1947, $1950 a, 1950 b, 1951,1968)$; Pathansali and Tokioka (1963); Schilp (1941); Thomson (1947, 1948); Tokioka (1952, $1956 a, 1956 b, 1962,1965 a, 1965 b)$, and Tokioka and Pathansali (1963).

The classification proposed by Tokioka (1965 a) divides Phylum Chaetognatha into two Classes, namely, Archisagittoidea (for the monotypic fossil genus Amiskwia Walcott, 1911 considered by Owre and Bayer (1962) to be most probably a pelagic nemertine), and Sagittoidea, the latter with two Orders Phragmophora and Aphragmophora. The former includes the families Spadellidae (genus Spadella Langerhans) and Eukrohnidae (genera Eukrohnia Ritter-Zahony, Heterokrohnia Ritter-Zahony, and Bathyspadella Tokioka). Order Aphragmophora is subdivided into two suborders-Flabellodontina (Family Krohnittidae, genus Krohnitta Ritter-Zahony) and Ctenodontina (Family Pterosagittidae for genus Pterosagitta Costa) and Family Sagittidae with eight genera-Sagitta s.str., Zonosagitta Tokioka, Serratosagitta Tokioka and Pathansali, Parasagitta Tokioka, Aidanosagitta Tokioka and Pathansali, Mesosagitta Tokioka, Solidosagitta Tokioka, and Flaccisagitta Tokioka). This classification envisages elevation of several species-groups into higher categories, recognising in all 15 genera for 65 taxa, including 3 subspecies, one variety and 3 forma.

Some earlier authors have attempted to group closely related species of Chaetognatha into "Couplets" (Michael, 1913) or species groups such as ' maxima'-group, 'neglecta'-group, ' hispida'-group, and so on (Thiel, 1938; Thomson, 1947; Tokioka, 1952; Furnestin, 1957; Colman, 1959; and others). According to Alvarino (1965) many of the groupings proposed may be of little value unless such groups are based on sound taxonomy and are realistic both in their genetical and ecological relations.

Our studies indicate that at present 33 species of Chaetognatha are known to inhabit the Indian Ocean and contiguous Seas. We have made no attempt to fit them into the classification proposed by Tokioka, nor tried to segregate them into species-groups for which more information will be needed. At present they are placed under four pelagic genera (Pterosagitta, Krohnitta, Eukrohnia, and Sagitta), and a benthic genus (Spadella). The material forming the basis of this study has come from the abundant collections of over 5000 plankton samples collected during the cruises of $\mathbf{R}$. V. VARUNA in the Indian Seas, and the collections made by the senior author during his participation in the $V$ Cruise of the U.S. Research Vessel ANTON BRUUN in the Indian Ocean from January to May 1964. The species 
that are present in our collections are marked with an asterisk $\left({ }^{*}\right)$ in the following list. Synonyms of the species are also indicated in the list in parenthesis with citation to relevant records from the Indian Ocean. The species are arranged alphabetically under each genus.

Genus Spadella Langerhans

1. Spadella cephaloptera (Busch), 1851

Genus Pterosagitta Costa

*2. Pterosagitta draco (Krohn), 1853

Genus Krohnitta Ritter-Zahony

*3. Krohnitta pacifica (Aida), 1897 [Syn. K. subtilis Ritter-Zahony, 1911 partim; Burfield and Harvey, 1926; Krohnia pacifica Varadarajan and Chacko, 1943; Krohnia kerberti Oye, 1918]

*4. Krohnitta subtilis (Grassi), 1881

Genus Eukrohnia Ritter-Zahony

5. Eukrohnia bathyantarctica David, 1958

*6. Eukrohnia bathypelagica Alvarino, 1962

*7. Eukrohnia fowleri Ritter-Zahony, 1909 [Syn. E. richardi Burfield and Harvey, 1926; E. hamata Thomson, 1947, partim]:

*8. Eukrohnia hamata (Moebius) 1875 [Syn. E. richardi Germain and Joubin, 1912]

*9. Eukrohnia minuta Silas and Srinivasan, 1969 Genus Sagitta Quoy and Gaimard

10. Sagitta bedfordii Doncaster, 1903 [Syn. S. pseudoregularis Oye, 1918]

*11. Sagitta bedoti Beraneck, 1895

12. Sagitta bipunctata Quoy and Gaimard, 1827 [Syn. S. hispida (nec Conant, 1895) Burfield and Harvey, 1926; George, 1952]

*13. Sagitta bombayensis Lele and Gae, 1936 [Syn. S. robusta George, 1949, partim]

*14. Sagitta decipiens Fowler, 1905 [Syn. S. neodecipiens Tokioka, 1959]

15. Sagitta demipenna Tokioka and Pathansali, 1963

*16. Sagitta inflata Grassi, 1881 [Syn. S. enflata of various authors; S. gardineri Doncaster, 1903; John, 1933, 1937; Lele and Gae, 
1936; S. enflata froma gardineri Tokioka, 1959; S. australis Johnston, 1909]

*17. Sagitta ferox Doncaster, 1903 [Syn. S. robusta (nec Doncaster, 1903) Burfield and Harvey, 1926; John, 19.33; Varadarajan and Chacko, 1943, partim; Thomson, 1947, 1948; George, 1952, partim; Tokioka, $1956 a, 1956 b, 1959$; Rao, $1958 a$, 1958 b; Rao and Ganapati, 1958; Sagitta ai Tokioka, 1939; S. planctonis (nec Steinhaus, 1896) Delsman, 1939; S. hispida (nec Conant, 1895) John, 1937 (?); Ghirardelli, 1947]

*18. Sagitta gazellae Ritter-Zahony, 1909 [Syn. S. lyra (nec Krohn' 1853) Thomson, 1947]

*19. Sagitta hexaptera d'Orbigny, 1834 [Syn. S. hexaptera froma magna Germain and Joubin, 1916]

*20. Sagitta hispida Conant, 1895

21. Sagitta johorensis Pathansali and Tokioka, 1963

*22. Sagitta lyra Krohn, 1853 [Syn. Pseudosagitta grimaldi Germain and Joubin, 1912; Sagitta lyra-gazellae Ghirardelli, 1950; Sagitta lyra typica Ghirardelli, 1950]

*23. Sagitta macrocephala Fowler, 1905

*24. Sagitta maxima (Conant) 1896 [Syn. Spadella maxima Conant, 1896]

25. Sagitta minima Grassi, 1881

26. Sagitta neglecta Aida, 1897 (Syn. Sagitta trichodermis Oye, 1918; S. tenuis (nec Conant, 1896) John, 1933]

*27. Sagitta pacifica Tokioka, 1940 [Syn. S. serratodentata (nec Krohn, 1853) Burfield and Harvey, 1926; Schilp, 1941; Ghirardelli, 1947; Rao, 1958 a; S. serratodentata 'pacifica' type Rao and Ganapati, 1958; Thomson, 1947, partim; S. serratodentata (variety 'Pacifica') Rao, 1958 b; S. serratodentata pacifica Tokioka, 1952, 1962]

28. Sagitta planctonis Steinhaus, 1896 [Syn. S. planktonis of some authors]

*29. Sagitta pulchra Doncaster, 1903 [Syn. S. weberi Oye, 1918]

*30. Sagitta regularis Aida, 1897

*31. Sagitta robusta Doncaster, 1903 [Syn. S. ferox Thomson, 1947; Tokioka, $1956 a, 1959]$ 
32. Sagitta tasmanica Thomson, 1947

*33. Sagitta zetesios Fowler, 1905 [Syn. S. planctonis (nec Steinhaus) Burfield and Harvey, 1926 (?); Schilp, 1941; Thomson, 1947 partim].

\section{Characters USED in Specific Identification}

The conventional meristic characters used in identifications, namely, hooks and teeth are variable with age. However, the determination of their variability based on graded series of material of different maturity stages will permit the use of these meristic characters. Besides the eye being pigmented or not, it is now known that in the former condition the arrangement of pigmented septa that separate the visual cupolae (pigmented cups) in the eye varies very little within the species, but differs from species to species. Other good systematic characters are: the presence of the collarette (lateral expansion of epidermis) and its nature and disposition; the relative lengths and sizes of lateral fins, the points of origin of the lateral fins (anterior fin in Sagitta) in relation to the ventral ganglion, the relative extension of the lateral fins on trunk and tail segment, and the rayed or rayless condition of the lateral fins; the ratio of tail segment in total length (varies with age, but can be relied upon when the range of variability for the species is known);, the structure, shape, size and the position of the seminal vesicles; the arrangement of developed ova in the advanced stage of vitellogenesis; the disposition of the sympathetic nerve cords from the ventral ganglion; the presence or absence of intestinal diverticula; the presence or absence of pigmentation of the intestine (in bathypelagic species); and the presence or absence of oil globules in the intestine.

The corona ciliata, though considered important, is known to vary considerably within the species and is difficult to observe in preserved material as it usually does not persist. The nature of the tips of the hooks (straight or hooked), the presence or absence of serrations (partially variable with age), and the shape of the hook; the relative lengths of the ovaries in fully matured (Stage-IV) specimens; relative hispidity; the size of the ventral ganglion; and the relative width of the intestine are used as additional systematic characters. Some authors have also considered the general aspects of the body such as flabbiness or turgidity; opacity, translucency, or transparency; the relative thickness and width of muscles; and the width of the lateral fields in relation to the width of the animal. 


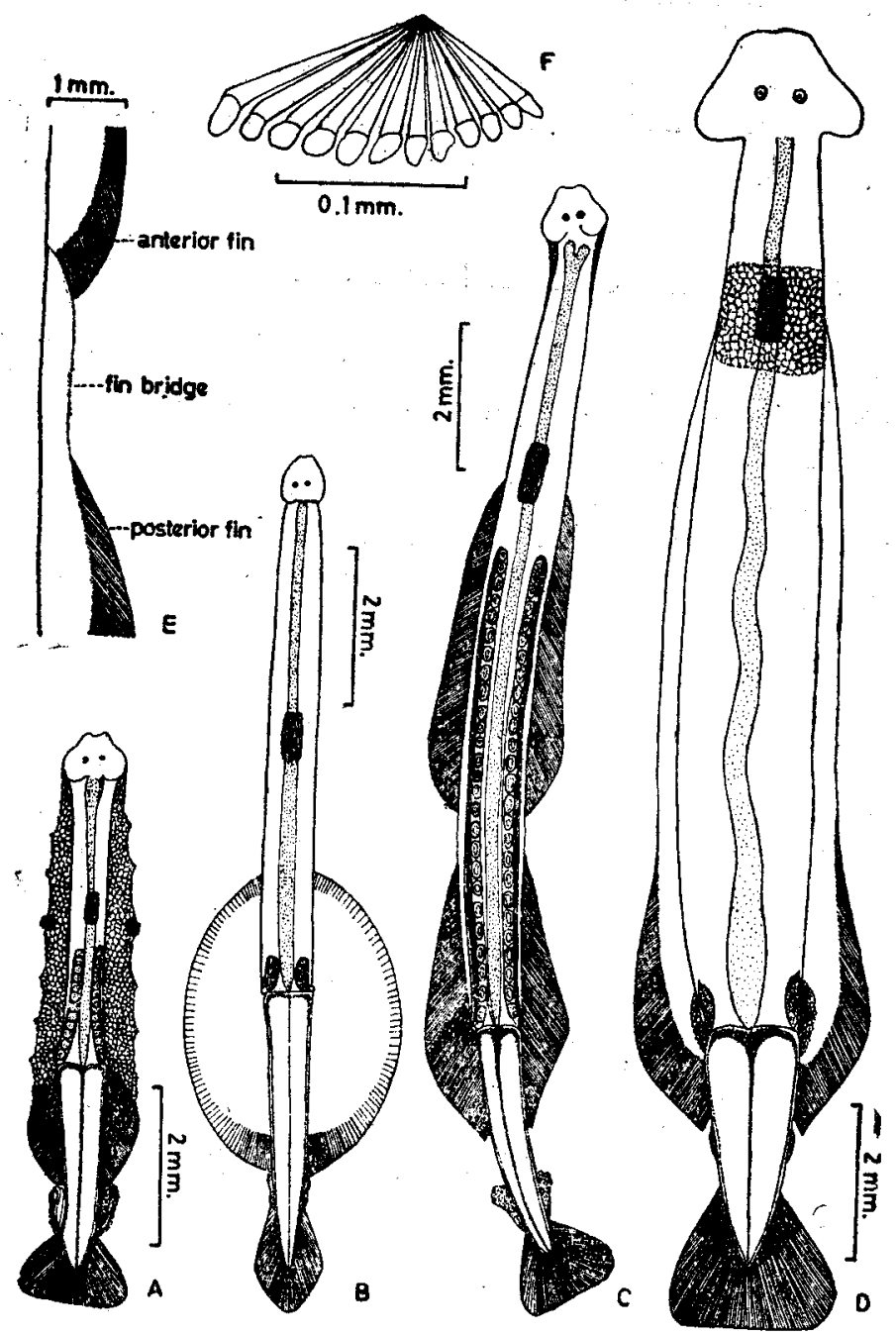

Fig. 1. A. Pterosagitta draco; B. Krohnitta subtilis; C. Sagitta decipiens; D. Eukrohnia fowleri; E. lateral fins of Sagitta lyra; and F. Arrangement of teeth in Krohnitta subtilis.

Key to the Genera and SPecies of Indian Ocean Chaetognatha

1. Two pairs of lateral fins (Fig. $1 \mathrm{C}$ : Sagitta Quoy and Gaimard).. 2 One pair of lateral fins (Fig. 1 A, B and D: Eukrohnia RitterZahony; Krohnitta Ritter-Zahony; Pterosagitta Costa; and Spadella Langerhans)

2. Collarette absent (Fig. 1 B) Collarette present (Fig. 1 A and C)

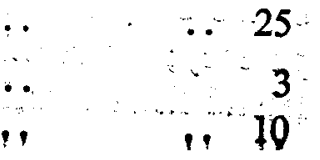


3. Eyes without pigment (Fig. 2 B).. Sagitta macrocephala Fowler Eyes with pigment (Fig. 2 C) ..

4. Finbridge connects anterior and posterior fins laterally (Fig. 1 E) 5

Finbridge absent (Fig. 1 C)

5. Tail segment less than 19 per cent of total length, anterior fin starts distinctly behind ventral ganglion (ova arranged in 4 or 8 rows)

Tail segment more than 19 per cent of total length; anterior fin starts opposite middle of ventral ganglion (ova arranged in 2 to 5 rows) .. $\quad$. $\quad$ Sagitta maxima (Conant)

6. Tail segment more than 15 per cent of total length; ova arranged in 4 rows (Fig. $2 \mathrm{O}$ ); distance between origin of anterior fin and ventral ganglion hardly exceeds length. of ventral ganglion

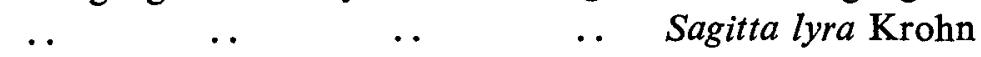

Tail segment less than 15 per cent of total length; ova arranged in 8 rows; distance between origin of anterior fins and ventral ganglion almost three times or more length of ventral ganglion $\quad$.. $\quad$.. Sagitta gazellae Ritter-Zahony

7. Species minute, mature specimens (Stage-IV) not exceeding $10 \mathrm{~mm}$; intestinal diverticula present; origin of anterior fin just behind ventral ganglion; ova arranged in one row (Fig. $2 \mathrm{~L}$ ) ..

Species large, mature specimens (Stage-IV) exceeding $10 \mathrm{~mm}$ and up to $40 \mathrm{~mm}$; intestinal diverticula absent; origin of anterior fin far behind ventral ganglion, gap being more than $\frac{3}{4}$ anterior fin length; ova arranged in 3 rows (Fig. $2 \mathrm{~N}$ ) , .. $\quad$..

8. Tail segment 17 to 21 per cent of total length; lateral fins rayed along margin; seminal vesicles not prominent, touching tail fin and separated from posterior fin by wide gap; ovaries short reaching up to mid-length of posterior fin on trunk; ova few

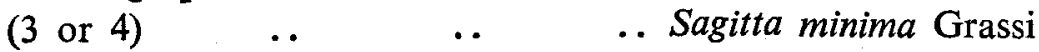

Tail segment 29 to 33 per cent of total length; lateral fins fully rayed; seminal vesicles conspicuously large and almost spherical, situated closer to posterior fins; ovaries long, extending beyond posterior end of anterior fins and even up to ventral ganglion; ova 9 or more .. 
9. Maximum size up to $25 \mathrm{~mm}$; anterior fin length more than 80 per cent of tail segment; origin of anterior fin almost midway between neck and tip of tail; seminal vesicles touching tail fin; anterior teeth 4 to 8 ; posterior teeth 4 to 13 ; ovaries not surpassing origin of anterior fins .. Sagitta inflata Grassi

Maximum size between 35 and $40 \mathrm{~mm}$; anterior fin length less than 80 per cent of tail segment; origin of anterior fin about midway between anterior end of head and tip of tail; seminal vesicles separated from tail fin by gap equal to its length (Fig. 2, I); anterior teeth 2 to 4 ; posterior teeth 2 to 6 ; ovaries extending beyond origin of anterior fins

$$
\begin{array}{lllll}
. & \text {. } & \text {. } & \text {.. } & \text { Sagitta hexaptera d'Orbigny }
\end{array}
$$

10. Concave internal margin of hooks with well-defined serrations (Fig. 2 D)

Concave internal margin of hooks without serrations

11. Ova arranged in one row; seminal vesicles with 4 to 10 chitinous 'teeth' antero-laterally (Fig. $2 \mathrm{~J}$ ) .. Sagitta pacifica Tokioka

Ova arranged in two rows; seminal vesicles without any chitinous 'teeth', but with soft protuberances or papillae

$$
\text { .. } \quad \text {.. } \quad \text {.. Sagitta tasmanica Thomson }
$$

12. Seminal vesicles touching both posterior fins and tail fin (Fig. $2 \mathrm{E}$ )

Seminal vesicles touching either posterior fins or tail fin or apart from both fins ..

13. Intestinal diverticula present; collarette well developed, extending from head to tail septum or even posterad; ova arranged in one or two rows

Intestinal diverticula absent; collarette short, restricted to neck region; ova arranged in 3 rows .. Sagitta bedoti Beraneck

14. Posterior teeth 10 to 15 ; hooks 5 to 8 ; collarette present from head to tail, but thickest from head to ventral ganglion from whence it extends backwards as a thin layer throughout body

Posterior teeth 18 to 23 ; hooks 9 or 10 ; collarette very conspicuous extending from head to slightly behind middle of posterior fin and more or less of uniform width throughout 


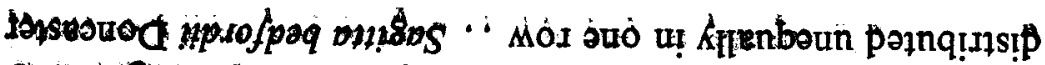

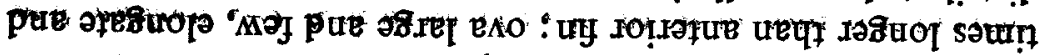

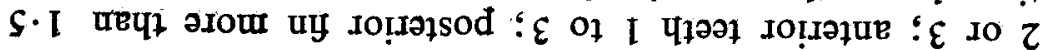

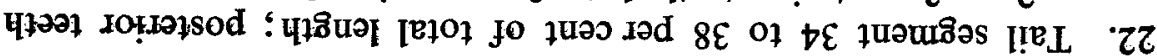
$z \tau$

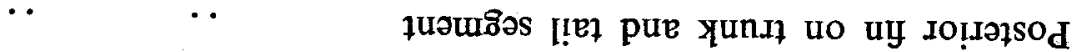
!IEsueqie

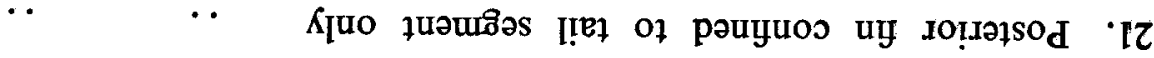

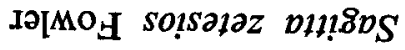

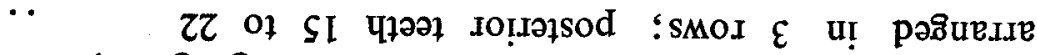

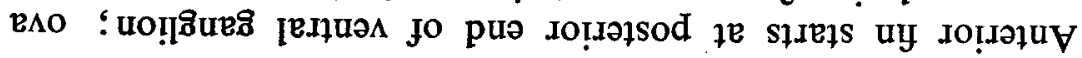
snequị: sịuołoupld pl!!8vS

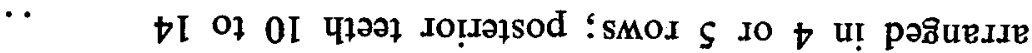

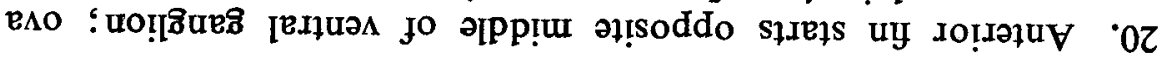
IZ

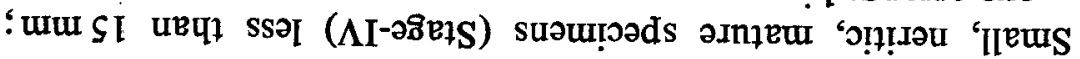
$0 z$

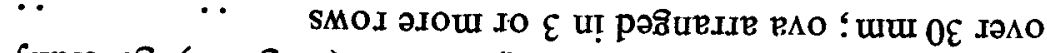

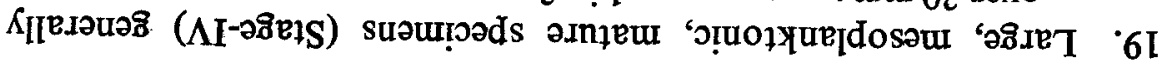

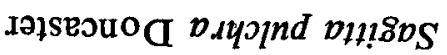

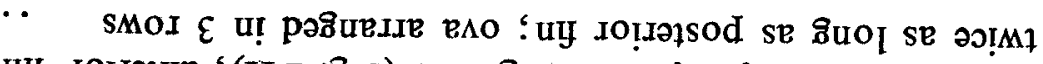

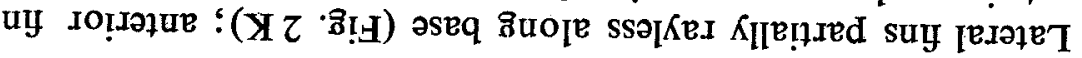

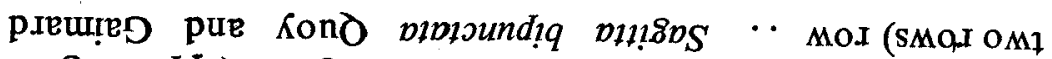

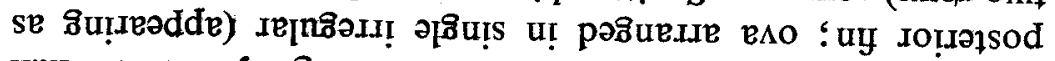

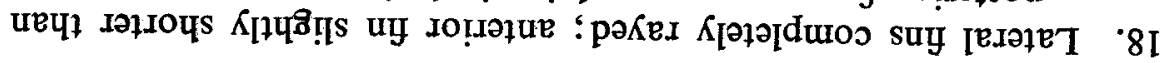
دәрМО

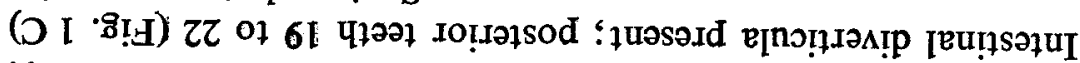

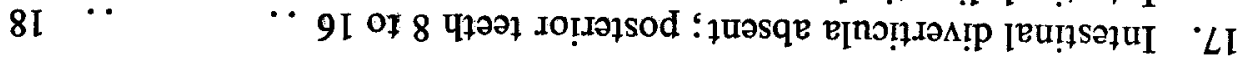

6I

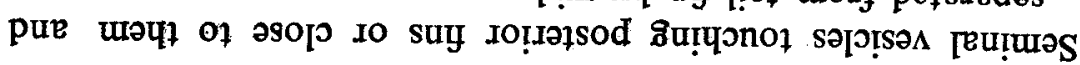

LI $\quad \cdots \quad$ ․

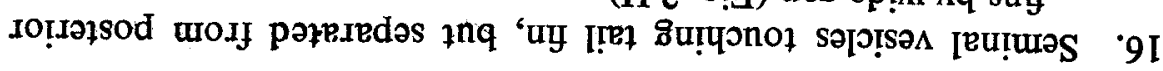

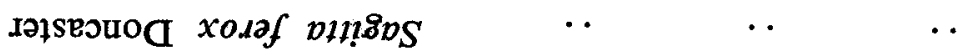
(W $\tau \cdot 8 !$ :

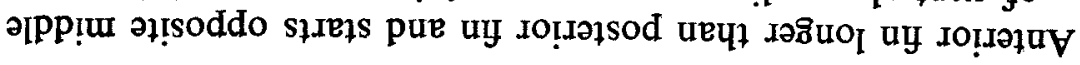

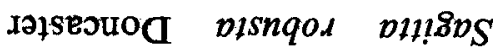

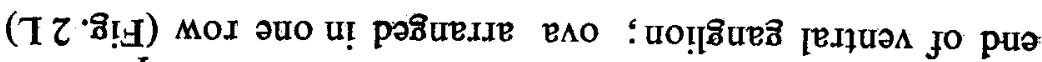

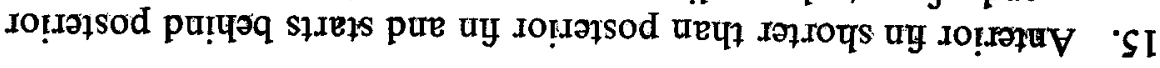


Tail segment 26 to 34 per cent of total length; posterior teeth 6 to 18 ; anterior teeth 4 to 10 ; posterior fin less than 1.5 times longer than anterior fin; ova oval to spherical and arranged in regular compact series in one row (Fig. $2 \mathrm{~L}$ ) $\quad . .23$

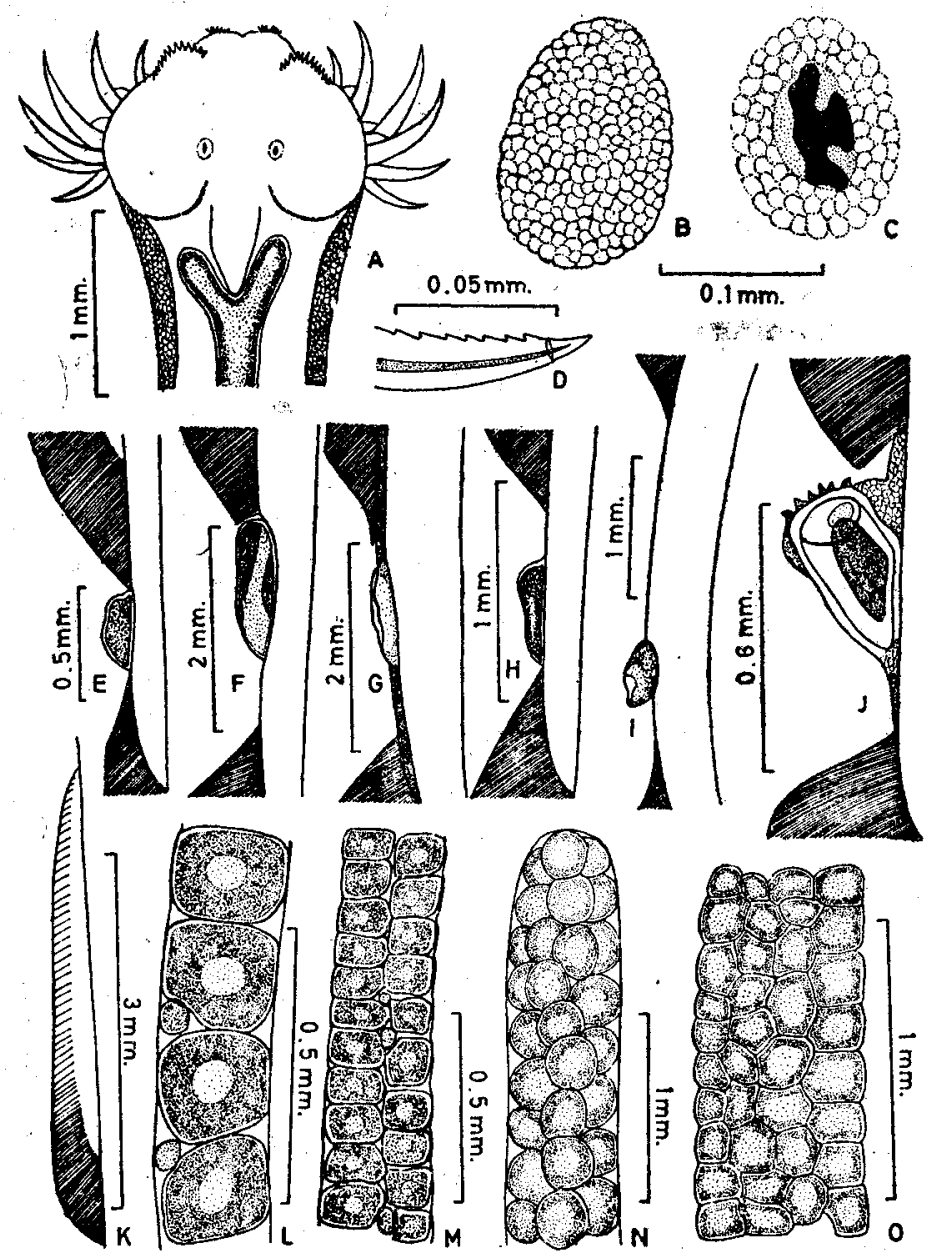

Frg. 2. A. Head of a typical Sagitta (S. ferox) showing details; B. Unpigmented eye ( $S$. macrocephala); C. Pigmented eye (S. robusta); D. Portion of a serrated hook ( $S$. pacifica); E. Seminal vesicle touching posterior lateral fin and tail fin $(S$. bedoti); F. Seminal vesicle touching posterior lateral fin (S. hispida); G. Seminal vesicle apart from posterior lateral fin and tail fin but closer to former (S. zetesios); H. Seminal vesicle touching tail fin (S. pulchra); I. Seminal vesicle apart from posterior lateral fin and tail fin but closer to latter ( $S$. hexaptera); J. Seminal vesicle with chitinous "teeth" antero-laterally ( $S$. pacifica); $K$. Anterior fin without fin rays along inner base (S.pulchra); L-O. Arrangement of ova in one row (S. robusta), in two rows (S. ferox), in three rows $(S$, inflata), and in four rows $(S$, lyra) respectively: 
23. Collarette extends from head to tip of tail; hispid condition not conspicuous; mature specimens (Stage-IV) less than $8 \mathrm{~mm}$. ..

Collarette extends from head to ventral ganglion; hispid condition conspicuous; mature specimens (Stage-IV) 8 to $12 \mathrm{~mm}$.

$$
\begin{array}{lllll}
. & & . & & .
\end{array} \quad \text { Sagitta hispida Conant }
$$

24. Collarette extends as a thick and wide layer from head to tail seminal vesicle eleongate; posterior teeth 2 to 6; anterior teeth 2 to 4 ; hooks 7 to $11 \quad$.. $\quad$ Sagitta regularis Aida

Collarette extends as a thin layer from head to tail; seminal vesicle roundish; posterior teeth 9 to 18 ; anterior teeth 5 to 7 ; hooks 6 to 8 ..

25. Digitate adhesive organs on tail segment present Spadella Langerhans) .. . . . Spadella cephaloptera (Busch)

Digitate adhesive organs on tail segment absent $\quad . \quad 2 \quad \ldots 26$

26. Two sets of teeth on either side of head; collarette massive extending as a conspicuous band from head to tail; lateral fin confined to tail segment (Pterosagitta Costa) (Fig. 1 A) .. $\begin{array}{llll}. . & \text {. } & \text {.. } & \text { Pterosagitta draco (Krohn) }\end{array}$

One set of teeth on either side of head; collarette poorly developed or absent; lateral fins extending from tail segment to trunk

27. Tail spatula-shaped (Fig. 1 B); lateral fins anteriorly extending to midway between tail segment and ventral ganglion; teeth arranged in form of a cone (Fig. 1 F) Krohnitta RitterZahony)

Tail posteriorly truncate or as in genus Sagitta (Fig. 1 D); lateral fins anteriorly extending up to ventral ganglion: arrangement of teeth as in genus Sagitta (Eukrohnia Ritter-Zahony). .

28. Lateral fins conspicuously broad and rayless except along margin; rays wide apart; ovaries in mature specimens (Stage-IV) do not surpass origin of anterior fin; ova arranged in two rows (Fig. 1 B)

Krohnitta subtilis (Grassi)

Lateral fins normal; fin rays more well defined covering over half of fin leaving internal anterior part rayless; ovaries in mature specimens (Stage-IV) reach ventral ganglion; ova arranged in one row 
29. Eyes with pigment; collarette present as a conspicuous band surrounding body in region of ventral ganglion and extends backwards as a thin layer on to tail segment thickening behind seminal vesicles (Fig. 1 D) .. Eukrohnia fowleri Ritter-Zahony

Eyes without pigment; Collarette when present inconspicuous as a thin layer from ventral ganglion to seminal vesicles or

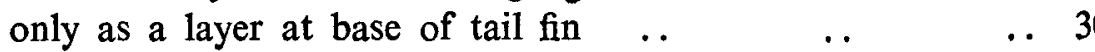

30. Collarette absent; hooks 11 or more (11 to 14 ) . . .. .. Eukrohnia bathyantarctica David

Collarette present; hooks less than 11 ( 7 to 10$) \quad$.. $\quad$.. 31

31. Tail segment less than 25 per cent of total length (19 to 25 percent); ova in mature specimens (Stage-IV) arranged in 4 rows $\quad$. $\quad$.. $\quad$ Eukrohnia hamata (Moebius)

Tail segment 25 per cent or more of total length ( 25 to 35 percent); ova in mature specimens (Stage-IV) arranged in one $\begin{array}{llllll}\text { or two rows } & \text {. } & \ldots & \ldots & \ldots & \text {.. }\end{array}$

32. Ovaries long, 30 per cent or more in total length; ova in mature specimens (Stage-IV) arranged in two rows; maturing ovaries coiled, especially towards tip: eyes with about 100 ommatidia; tips of jaw hooks curved and at almost right angles to shaft .. $\quad$. $\quad$ Eukrohnic bathypelagica Alvarino

Ovaries short, hardly 10 per cent of total length; ova in mature specimens (Stage-IV) arranged in one row; maturing ovaries cylindrical and straight, eyes with less than 20 ommatidia; tips of jaw hooks almost straight 


\section{General Remarks}

The status and systematic position of some species recorded from Indian Seas are uncertain. For instance, the record of 'Sagitta planktonis' by George (1952) considered by Alvarino (1965) to be a synonym of Sagitta zetesios needs further study. Both S. planctonis and S. zetesios are mesoplanktonic species, and the illustrations given by George does not agree with these species. Other such instances are discussed by Silas and Srinivasan (1969).

Apparently, only cursory examinations have been made of material of Spadella from the Indian Ocean resulting in the record of only a single species, S. cephaloptera by earlier workers. At present the genus is known from at least ten nominal species from the Atlantic and Pacific Oceans and the Mediterranean (Owre, 1963; Tokioka, 1965a). More careful scrutiny of material of this benthic genus from the Indian Ocean is bound to bring to light additional records.

Alvarino (1965) expressed doubts regarding the validity of the pelagic genus Heterokrohnia Ritter-Zahony (1911) indicating that the type H. mirabilis Ritter-Zahony (1911) described from the Indian Ocean Sector of the Antarctic may be based on mutilated specimens of Sagitta lyra. However, recently Marumo and Kitou (1966) have described a new species of Heterokrohnia (H. bathybia) from the Western North Pacific giving more weight to the validity of this genus. The occurrence of this genus in the subtropical waters of the Indian Ocean cannot be ruled out.

The known distribution of Sagitta friderici Ritter-Zahony (1911), S. marri David (1956), S. oceania Grey (1930), and S. tenuis Conant (1896) are close to the boundaries of the Indian Ocean. Apparently, more intensive sampling may show the occurrence of some of these species within the limits of the Indian Ocean. Insufficient sampling is primarily responsible for our ignorance about the natural distribution of several species, particularly those inhabiting the mesopelagic and bathypelagic realms.

It is hoped that the aid to the identification of Chaetognatha of the Indian Ocean given here would facilitate the work of planktologists currently engaged in studying Indian Ocean zooplankton and in particular those interested in chaetognaths.

\section{ACKNOWLEDGEMENT}

Our sincere thanks are due to Dr. S. Jones, Director, Central Marine Fisheries Research Institute, Mandapam Camp, for his encouragement in 
the course of this work. The Senior Author also wishes to express his thanks to the United States National Science Foundation and the U.S. Program in Biology, International Indian Ocean Expedition for facilities given to him for making plankton collections during the $V$ Cruise of R. V. ANTON BRUUN in the Indian Ocean enabling him to obtain comparative material used in this study.

\section{REFERENCES}

The original references of species and synonyms in the list of Indian Ocean species mentioned earlier are available in standard works such as Thomson (1947) and Alvarino (1965). Hence, these are not included here unless referred to in the rest of the text.

Alvarino, A.

Bigelow, H. B.

Colman, J. S.

David, P. M.

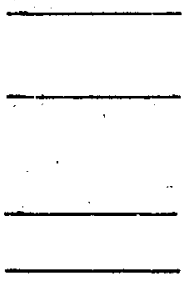

Fagetti, G. E.
. "Chaetognatha of the Monsoon Expedition in the Indian Ocean," Pacif. Sci., 1964 a, 28 (3), 336-48.

. "Report on the Chaetognatha, Siphonophorae and Medusae of the Monsoon Expedition in the Indian Ocean," Prelim. Results Scripps Inst. Invest. Indian Ocean. Exped. Monsoon and Lusiad (1960-1963), Rep. Scripps. Inst. Oceanogr., 1964 b, 103-108, 209-12.

.. “Chaetognaths," Oceanogr. Mar. biol. Ann. Rev., 1965, 3, 115-94.

.. "The Chaetognatha of the Naga Expedition (1959-1961) in the South China Sea and the Gulf of Thailand. Part I. Systematics," Naga Rep. Univ. Calif. Scripps Inst. Oceanogr., 1967, 4, 1-197.

.. "Plankton of the off-shore waters of the Gulf of Maine,", Bull. U.S. Bur. Fish., 1926, 40, 1-509.

.. "The Rosaura Expedition, 1937-38, Chaetognatha," Bull. Br. Mus. nat. Hist. Zool., 1959, 5, 221-53.

. “The distribution of Sagitta gazellae Ritter-Zahony," "Discovery" Rept., 1955, 27, 235-78.

. "The distribution of Chaetognaths of the Southern Ocean," Ibid., 1958 a, 29, 199-228.

.. "A new species of Eukrohnia from the Southern Ocean with a note on fertilization," Proc. Zool. Soc. London, $1958 b, 131,597-606$.

.. "Chaetognatha," BANZARE Rept., 1959, Ser. B, 8, 73-79.

.. "Some aspects of speciation in the Chaetognatha," Syst. Ass. Publ. No. 5, Speciation in the Sea, 1963, 129-43.

.. "New record of Eukrohnia bathyantarctica David, 1958, from the Gulf of Mexico and Caribbean Sea," Bull. Mar. Sci., 1968, 18, 383-87. 
Fraser, J. H.

Furnestin, M. L.

George, P. C.

Ghirardelli, E.

Marumo, R., and Kitou, $M$.

Michael, E. L.

Owre, H. B.

and Bayer, M. B.

Pathansali, D. and Tokioka, T.

Ponomareva, L. A.
.. "The distribution of chaetognatha in Scottish waters during 1936, with notes on the Scottish Indicator Species," Cons. int. Explor. Mer. Journ. du Cons., 1937, 12, 311-20.

.. "The distribution of chaetognatha in Scottish waters in 1937," Ibid., 1939, 14, 25-34.

.. "The occurrence of unusual species of chaetognatha in Scottish plankton collections," Journ. Mar. biol. Assoc. U.K., 1949, 28, 489-91.

.. "The chaetognatha and other zooplankton of the Scottish area and their value as biological indicators of hydrological conditions," Mar. Res. Scotland, 1952, 2, 5-52.

.. "Chaetognaths et zooplankton du secteur Atlantique Morocain," Revue Trav. Inst. (Sci., Tech.) Pech. Marit., 1957, 21, 1-356.

.. 'Quelques echantillons de zooplancton dy golfe d'Eylath (Akaba)," Bull. Sea Fish. Res. Stn., Haifa, 1958, 16, 1-9.

.. "A systematic account of the chaetognaths of the Inr an Coastal waters, with observations of their seast al fluctuations along the Malabar Coast," Proc. Nat. Inst. Sci. India, 1952, 18, 657-89.

.. "Chaetognathi raccolti nel Mar Rosso e nell'oceano Indiano dalla nave 'Cherso", Boll. Pesca Piscie. Idrobiol., 1947, 2, 253-70.

.. "Osservazioni biologiche e systematische sui Chaetognathi dalla baia di Villefranche sur Mer," Ibid., $1950 a$, $5,105-27$.

.. "Morfologia dell'apparechio digerente in Sagitta minima Grassi," Boll. Zool., Suppl., 1950 b, 17, 555-67.

.. "Some aspects of the biology of the chaetognaths," $A d v$. mar. Biol., 1968, 6, 271-375.

.. "A new species of Heterokrohina (Chaetognatha) from the Western North Pacific," Bull. Soc. franco-Japonaise d'Oceanogr., 1966, 4, 178-83.

.. "Vertical distribution of the Chaetognatha of the San Diego region in relation to the question of isolation vs. coincidence," Am. Nat., 1913, 47, 17-49.

.. "The genus Spadella (Chaetognatha) in the Western North Atlantic Ocean, with descriptions of two new species," Bull. Mar. Sci. Gulf. Caribb., 1963, 13, 378-90.

.. "The position of the Middle Cambrian Fossil Amiskwia Walcott," J. Palaeont, 1962, 36, 1361-63.

"A new chaetognath, Sagitta johorensis n.sp. from Malay waters," Publs. Seto. Mar. Biol. Labl., 1963, 11, 105-07.

.. Trud. Inst. Okeanol. 1957, 20, 185-99. 
Ritter-Zahony, $\mathbf{R}$.

Russel, F. S.

Schilp, H.
.. "Revision der chaetognathen," Dt. Suedpol. Exped., 1901-903, 1911, 13, Zool., 5, 1-71.

.. "On the value of certain plankton animals as Indicators of movements in the English Channel and North sea," Journ. Mar. Biol. Ass. U.K., 1935 a, 20, 309-32.

.. "A review of some aspects of Zooplankton Research," Cons. int. Explor. Mer., Rapp. et Proc.-Verb., 1935 b, 95, 5-30.

.. "Hydrographic and Biological conditions in the North Sea as indicated by Plankton Organisms," Cons. int. Explor. Mer., Journ. du Cons., 1939, 14, 171-92.

.. "The Chaetognatha of the Snellius Expedition," Temminckia, 1941, 6, 1-99.

Silas, E. G. and Srinivasan, M. .. "A new species of Eukrohnia from the Indian Seas with notes on three other species of Chaetognatha." J. Mar. biol. Ass. India, 1969, 10, 1-33 (Also See: Adv. Abstr. Contr. Fish. Aquat. Sci. India, 3, Abstract No. 235, p. 179).

Th:-1, M. E.

Thomson, J. M.

Tokioka, T. and Pathansali, D.
.. Die Chaetognathen "Bevoelkerung des Suedatlandischen Ozean," Wiss. Ergebn. Dt. Atlant. Exped. Meteor, 1925-27, 1938, 13, 1-110.

.. "The chaetognatha of South-Eastern Australia," Rep. Div. Fish. Coun. Sci. Ind. Res. Aust., 1947, 14, 4-43.

. "Some Chaetognatha from Western Australia," J. Roy. Soc. W. Aust., 1948, 31, 17-18.

.. "Chaetognaths collected chiefly from the Bays of Sagami and Suruga with some notes on the shape and structure of the seminal vesicles," Rec. Oceanogr. Works, Japan, 1939, 10, 122-50.

.. "Chaetognaths of the Indo-Pacific," Ann. Zool. Jap., 1952, 25, 307-16.

.. "The chaetognatha and appendicularians collected in the Central part of the Indian Ocean," Publ. Seto. Mar. biol. Lab., 1956 a, 5, 197-202.

.. "On chaetognaths and appendicularians collected by Mr. Sagara in the Arafura Sea in May-August 1955," Ibid., $1956 b, 5$, 203-08.

.. "The outline of the investigations made on Chaetognatha of the Indian Ocean," Inf. Bull. Planktol. Japan, 1962, 8, 5-11.

.. "The Taxonomical outline of Chaetognatha," Publ: Seto. Mar. biol. Lab., 1965 a, 12, 235-57.

.. "Supplementary Notes on the Systematics of Chaetognatha," Ibid., $1965 b, 13,231-42$.

.. "Another new chaetognatha from Malay Waters, with a proposal of grouping some species of Sagitta into subgenera," Ibid., 1963, 11, 119-23. 